\title{
PERBEDAAN PENANGANAN PERILAKU SISWA YANG MENGGANGGU DALAM PROSES PEMBELAJARAN KLASIKAL SEKOLAH MENENGAHOLEH GURU LAKI-LAKI DAN PEREMPUAN
}

\author{
Amirah Diniaty \\ Fakultas Tarbiyah \& Keguruan UIN Suska Riau \\ Email: amirah.diniaty@gmail.com
}

\begin{abstract}
Female teacher tends to recognize irritating behavior of the pupils (Prilaku Siswa yang Menggangu/PSM) in learning process compared with male teacher. However, the difference is less significance. The most dominant form of PSM happening to the pupil is attention seeker in which the pupil talk in classroom during the learning process. Even though PSM is rare, it still requires an appropriate measure conducted by the teacher toward the PSM in order to lessen the frequency. The finding of this research shows that male teacher stricter than female teacher in handling PSM.
\end{abstract}

Key words : Dissenting Perspectives, Irritating Pupils Behavior (PSM), Classical Learning Process, Male Teacher, Female Teacher.

\section{PENDAHULUAN}

Pendidik yang dikenal sebagai guru di tingkat sekolah dasar dan menengah, merupakan sebuah profesi yang menyelenggarakan pembelajaran bagi siswa. Profesi ini dapat dilakukan oleh individu dari jenis kelamin laki-laki dan perempuan di negara Indonesia, karena tidak adapersyaratan menjadi guru yang dibatasi berdasarkan jenis kelamin.Persyaratan utama menjadi guru adalah profesionalitas,sehingga laki-laki dan perempuan mempunyai status dan kedudukan yang sama untuk profesi ini.

Jika kita lihat dari kebutuhan manusia untuk mewariskan kebudayaan dan filsafat hidup masyarakat kepada generasi muda, maka proses pembelajaranmenjadi sebuah keharusan.1Namunkarena faktor budaya, dulunya penyelenggara pembelajaran lebih didominasi oleh kaum laki-laki.

Kilas balik sejarah menggambarkan bahwa dulukegiatan pembelajaran dilakukan dalam bentuk tutorial langsung, cerita rakyat, upacara adat, dongeng, nyanyian, dan latihan kepada anak di lapangan (sawah, ladang) dan dilingkungan keluarga. Waktu itu, sistem pendidikan langsung masih bisa dilakukan, karena hampir semua orang dewasa di suatu masyarakat menguasai muatan budaya yang harus dikuasai anak. Disisi lain anak mengamati dan belajar dari apa yang dilakukan orang dewasa di lingkungan sosial mereka. ${ }^{2}$

Perkembangan pengetahuan dan teknologi yang tumbuh pesat dan masyarakat yang berkembang cepat dalam zaman moderen, menyebabkan tidak semua orang dewasa di suatu masyarakat menguasai muatan budaya yang perlu dimiliki anak, agar fungsional di masyarakat. Sehingga sistem pendidikan tradisional tersebut tidak lagi dilakukan, ${ }^{3}$ dan begitu juga dengan peran pendidik dari kaum perempuan. Kenyataannya ini melahirkan 
lembaga pendidikan formal seperti sekolah dan ruangan tertentu yang disebut kelas untuk proses pembelajaran, yang dikelola oleh guru laki-laki dan perempuan.

Mulyadi $^{4}$ menegaskan, kelas merupakan sistem sosial dengan proses kelompok (group process) sebagai intinya. Jadi kelas merupakan tempat terjadinya pendidikan atau lebih khususnya proses pembelajaran, yang berisi sejumlah peserta didik yang berinteraksi dengan pendidikan yaitu guru laki-laki dan perempuan untuk mencapai tujuan pembelajaran tersebut.

Proses interaksi guru laki-laki dan perempuan dengan siswa dalam pembelajaran di kelas, terjadi dinamis. Hasil penelitian Sri Sukarti ${ }^{5}$ menemukan perbedaan yang signifikan dari prestasi belajar siswa berdasarkan jenis kelamin guru; laki-laki dan perempuan. Menurut Sri Sukarti (2013), hal ini diduga karena guru laki-laki lebih banyak mempunyai waktu dan kesempatan dalam mengembangkan diri dalam mengajarnya sementara guru perempuan sesuai dengan kondisinya harus mampu membagi perannya dalam mengajar dan mengurus rumah tangganya.

Kenyataannya dalam pendidikan kita banyak pembelajaran diselenggarakan guru laki-laki dan perempuan dalam kelas-kelas di sekolah yang jumlah siswanya melebihi standar. Hal ini terjadi karena kebijakan yang ada baru untuk mencapai kuantitas (jumlah siswa), belum pada pencapaian kualitas (mutu) pembelajaran. $\mathrm{T}^{\prime} \mathrm{uu}^{6}$ menjelaskan, semakin besar jumlah siswa dalam satu kelas, semakin tidak efektif kegiatan pembelajaran. Sebaliknya semakin kecil jumlah siswa dalam kelas, guru dapat memberikan perhatian penuh pada siswa.

Oleh sebab itu seperti banyak konteks sosial lainnya, setiap kelas berkemungkinan memiliki beberapa siswa yang terarah untuk tidak melibatkan diri dalam kegiatan kelas, dan dengan demikian menjadi kekuatan yang dapat menggangu. ${ }^{7}$ Gangguan dapat terbentang mulai dari siswa mengobrol ketika mereka seharusnya mendengarkan guru atau menolak bergabung dengan kegiatan kelompok kecil sampai meneriaki guru dan menghentakkan kaki meninggalkan ruangan. Gangguan ini tentulah tidak diharapkan oleh guru dan siswa lainnya. Hasil riset ${ }^{8}$ menjelaskan kelas yang ribut sungguh-sungguh menghambat aktivitas belajar siswa.Kelas yang bising lebih lanjut menghambat pembelajaran siswa yang memiliki gejala kurang perhatian.

Selanjutnya Arends ${ }^{9}$ mengklasifikasi perilaku siswa yang mengganggu (selanjutnya disingkat PSM) dari aspek perorangan dan kelompok, yang merugikan siswa bersangkutan dan siswa lain, yaitu; (a) Mencari perhatian (attention-getting behaviors) berupa pelanggaran disiplin, (b) Mencari kekuasaan (power-seeking behaviors) berupa tingkah laku yang tidak pantas dilakukan siswa saat pembelajaran klasikal, (c) Mencari 
balas dendam (reverenge-seeking behavior) berupa respon langsung yang negatif, (d) menampilkan ketidakmampuan yaitu dalam bentuk sama sekali menolak untuk mencoba melakukan apapun karena yakin hanya kegagalanlah yang menjadi bagiannya.

Keempat tindakan individu itu akan mengakibatkan terbentuknya pola tingkah laku yang sering dijumpai pada siswa yaitu: (1) Pola aktif konstruktif yaitu pola tingkah laku yang ekstrem, ambiguous untuk menjadi superstar di kelasnya dan berusaha membentuk guru dengan vitalitas dan sepenuh hati, (2) Pola aktif destruktif yaitu pola tingkah laku yang diwujudkan dalam bentuk banyolan, suka marah, kasar dan memberontak, (3) Pola pasif konstruktif yaitu pola yang menunjukkan kepada satu bentuk tingkah laku yang lambat dengan maksud supaya selalu dibantu dan mengharapkan perhatian, dan (4) Pola pasif destruktif yaitu pola tingkah laku yang menunjukkan kemalasan (sifat malas) dan keras kepala.

Adapun faktor penyebab sebagian besar PSM menurut Arends ${ }^{10}$ adalah ;(1) Siswa beranggapan kegiatan sekolah membosankan dan tidak relevan, maka berusaha menjauhinya, (2) Kehidupan siswa di luar sekolah (keluarga dan masyarakat) menghasilkan masalah psikologis dan emosional yang mereka tunjukkan di sekolah, (3) Siswa terpenjara di dalam sekolah yang memiliki disposisi otoriter yang menyebabkan mereka memberontak, (4)
Pemberontakan siswa dan pencarian perhatian merupakan bagian dari proses menjadi dewasa.

Berkenaan dengan itu guru laki-laki dan perempuan dituntut mampu menghadapi PSM dengan bijaksana saat pembelajaran klasikal berlangsung. Sehingga tidak merugikan diri siswa bersangkutan dan siswa lain, dan menjadikan perilaku siswa kembali positif dan berdisiplin. Dalam hal ini Permendikbud Nomor 82 tahun 2015 tentang Pencegahan dan Penanggulangan Tindakan Kekerasan di Lingkungan Sekolah harus dijadikan sebagai rambu-rambu sehingga tidak ada tindakan kekerasan terhadap siswa. Selain itu Peraturan Menteri Negara Pemberdayaan Perempuan dan Perlindungan Anak Republik Indonesia Nomor 8 Tahun 2014 tentang Kebijakan Sekolah Ramah Anak, menuntut guru harus memperlakukan siswa dalam konteks mendidik bukan menghukum.

Menurut data ikhtisar eksekutif strategi nasional penghapusan kekerasan terhadap anak tahun 2016-2020 Kementerian Pemberdayaan Perempuan dan Perlindungan Anak (Kemen-PPPA), sebanyak 84 persen siswa pernah mengalami kekerasan di sekolah.11 Lebih lanjut data ICRW tahun 2015 mendeskripsikan 45\% siswa laki-laki menyebutkan bahwa guru atau petugas sekolah merupakan pelaku kekerasan. 
Prayitno $^{12}$ menggambarkan bentuk kekerasan berupa hukuman guru atas kesalahan siswa yang menjadikan sekolah sebagai "lembaga penghukuman" itu, di antaranya:

...dengan menyuruh mereka membersihkan kelas, mengepel lantai, melap kaca, menuliskan kata "saya tidak akan berbuat itu lagi" sekian puluh kali. Atau yang lebih sadis seperti: disuruh lari berkeliling lapangan sekian kali putaran tanpa memakai sepatu dan baju; berdiri pada satu kaki sampai selesai jam pelajaran atau bahkan sampai menskor atau tidak mengizinkan untuk sekolah. Itu tidaklah efektif. Selain tidak relevan dengan materi pelajaran, kadang tidak manusiawi, juga dapat menimbulkan sikap negatif pada si pelaku. Proses perbaikan diri tidak terjadi, sikap antipati atau bibit balas dendam mungkin justru ditumbuhkan.

Terkait dengan itu Prayitno ${ }^{13}$ menjelaskan bahwa banyak pihak, bahkan juga para pendidik (masih) berpendapat bahwa kekerasan terhadap peserta didik diperlukan dalam pendidikan. Perlunya kekerasan dalam pendidikan itu dirumuskan dengan memposisikan "hukuman sebagai alat pendidikan". Implikasi rumusan tersebut ialah bahwa: "jika pendidikan mau berhasil, pendidik perlu menerapkan hukuman terhadap peserta didik".
Sayangnya, penafsiran yang lebih jauh dan menjadi tidak proposional tentang "perlunya hukuman" itu menimbulkan tindakan kekerasan terhadap peserta didik sampai dengan kondisi di luar batas kewajaran.

Ajaran Islam sebagaimana hadis Nabi Muhammad SAW yang beliau katakan pada Aisyah (HR Muslim dikutip dalam Muhammad Nabil Kazhim,14 menjelaskan: Sesungguhnya Allah itu maha lembut dan mencintai kelembutan dan memberikan kepada kelemahlembutan apa yang tidak diberikannya kepada kekerasan dan tidak juga kepada selainnya. Hadis ini menegaskan bahwa hendaklah dalam menyelenggarakan pendidikan menghindari pemberian hukuman fisik pada peserta didik, karena kelemahlembutan lebih utama dan baik. Sehubungan dengan itu Kazhim ${ }^{15}$ mengutip pendapat Umar Basyir Att Thuwaibi mengatakan bahwa:

Punishment adalah pintu negatif dalam pendidikan. Ia akan menggiring seseorang menuju kehancuran, sehingga hidup dalam kecemasan, ketakutan, dan kegagalan. Sesungguhnya kebiasaan memukul anak dalam mendidiknya menunjukkan bahwa kita sebagai orang dewasa salah dalam memilih metode yang tepat sehingga dapat menyentuh jiwa dan meluruskan perilakunya.

Kondisi real yang terjadi di lapangan menarik untuk diteliti dari aspek gender 
yaitu bagaimana perbedaan penangananPSM dalam proses pembelajaran klasikal di sekolah menengah oleh guru laki-laki dan perempuan. Pertanyaan penelitian yang ingin dijawab adalah: (1) Apa saja bentuk PSM yang terjadi dalam proses pembelajaran klasikal menurut guru laki-laki dan perempuan? (2) Adakah perbedaan bentuk penanganan PSM oleh guru laki-laki dan perempuan?

\section{METODOLOGI PENELITIAN}

Jenis penelitian ini adalah deskriptif kuantitatif.Penelitian dilakukan di SMK Kehutanan Pekanbaru. Data diambil dari 27 orang guru yang terdiri dari guru laki-laki 13 orang dan 14 orang guru perempuan pada tahun ajaran 2016/2017 secara random sampling dengan cara by incident yaitu guru yang bersedia mengisi instrumen penelitian berupa angket dengan suka rela.

Instrumen yang digunakan untuk mengumpulkan data adalah angket yang disusun dengan indikator: (1) bentuk PSM yaitu; Mencari perhatian (attention-getting behaviors), Mencari kekuasaan (power-seeking behaviors), Membalas dendam (reverenge-

seeking behavior), menampilkan ketidakmampuan, (2) Penanganan PSM oleh guru di kelas dengan indikator guru membiarkan, menghukum, dan tegas yang mendidik.

Angket diisi dengan pilihan jawaban skala likert yaitu selalu, sering, jarang, kadang dan tidak pernah. Hasil pengumpulan data angket diolah dengan statistik persentase sehingga tergambar;bentuk PSM menurut guru dan bentuk penanganannya yang dikelompokkan berdasarkan jenis kelamin guru laki-laki dan perempuan.Untuk melihat perbedaan penanganan PSM antara gurulaki-laki dan perempuan dilakukan analisis uji-t.

\section{HASIL PENELITIAN}

\section{Perbedaan Bentuk PSM Menurut Guru} Laki-Laki dan Perempuan

Hasil pengolahan angket melalui ttest dengan program SPSS untuk melihat perbedaan bentuk PSM yang terjadi dalam proses pembelajaran menurut guru laki-laki dan perempuan, adalah sebagai berikut:

Tabel 1

Hasil uji t-test bentuk PSM menurut guru laki-laki dan perempuan

Independent Samples Test

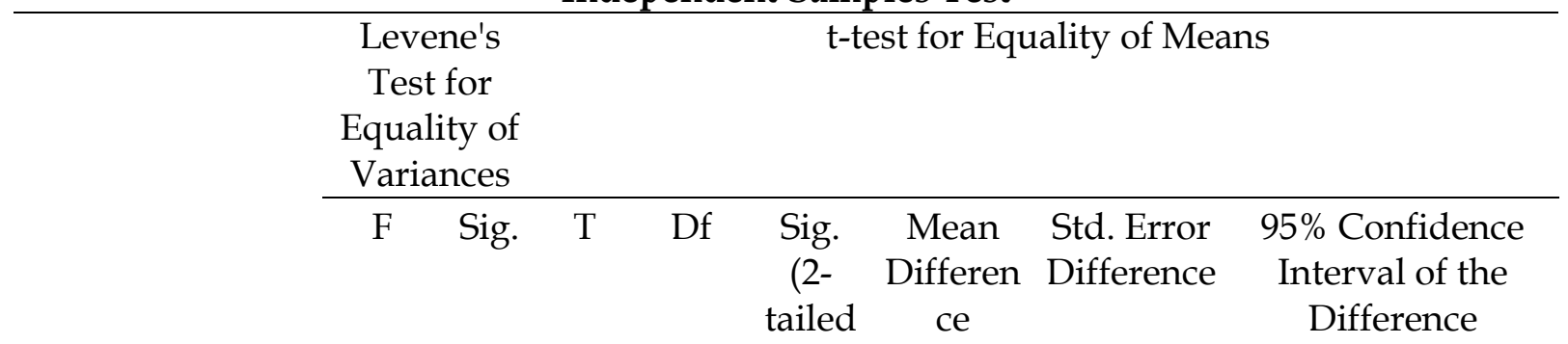




\begin{tabular}{|c|c|c|c|c|c|c|c|c|c|c|}
\hline & & & & & & ) & & & Lower & Upper \\
\hline \multirow{3}{*}{$\begin{array}{l}\text { Bentuk } \\
\text { PSM }\end{array}$} & $\begin{array}{l}\text { Equal } \\
\text { variance } \\
\mathrm{s}\end{array}$ & .121 & .731 & .323 & 25 & .749 & 1.29121 & 3.99479 & -6.93622 & 9.51864 \\
\hline & assumed & & & & & & & & & \\
\hline & $\begin{array}{l}\text { Equal } \\
\text { variance } \\
\text { s not } \\
\text { assumed }\end{array}$ & & & .322 & $\begin{array}{r}24.27 \\
2\end{array}$ & .750 & 1.29121 & 4.00967 & -6.97945 & 9.56187 \\
\hline
\end{tabular}

Hasil uji t-test ini menggambarkan levene's test $p=0.120>0,05$ yang berarti data homogen. Hasil t-tes for equality of mean diperoleh gambaran bahwa $\mathrm{p}=0.749$ dan $\mathrm{p}=0750>$ dari 0,05 yang berarti tidak ada perbedaan bentuk PSM menurut guru perempuan dan guru laki-laki. Untuk melihat perbedaan lebih spesifik dari dari rerata means yang dimiliki dari guru perempuan dan laki-laki tentang bentuk PSM dalam proses pembelajaran, dapat dilihat dalam tabel berikut:

Tabel 2

Perbedaan mean bentuk PSM menurut guru laki-laki dan perempuan

Group Statistics

\begin{tabular}{|c|c|c|c|c|c|}
\hline & \multicolumn{4}{|c|}{1} & \multirow[b]{2}{*}{ Std. Error Mean } \\
\hline & Guru & $\mathrm{N}$ & Mean & $\begin{array}{c}\text { Std. } \\
\text { Deviation }\end{array}$ & \\
\hline \multirow{2}{*}{$\begin{array}{l}\text { Bentuk } \\
\text { PSM }\end{array}$} & $\begin{array}{l}\text { Peremp } \\
\text { uan }\end{array}$ & 14 & 22.2143 & 9.87755 & 2.63989 \\
\hline & $\begin{array}{l}\text { Laki- } \\
\text { laki }\end{array}$ & 13 & 20.9231 & 10.88165 & 3.01803 \\
\hline
\end{tabular}

Data dalam tabel tersebut memperlihatkan bahwa guru perempuan menilai bentuk PSM lebih tinggi dibandingkan dengan guru lakilaki (22.2143 > 209231). Guru perempuan ternyata lebih merasakan adanya PSM terjadi di kelas dibandingkan dengan guru laki-laki. Namun perbedaan ini tidak signifikan.
Selanjutnya persentase bentuk PSM yang diungkapkan guru laki-laki dan perempuan dijelaskan perindikator sebagai berikut:

a. Bentuk PSM kategori mencari perhatian (attention-getting behaviors) dengan cara melanggar disiplin, digambarkan dalam tabel berikut:

Tabel 3

Bentuk PSM attention-getting behaviorssaat Pembelajaran di Kelas menurut Guru Laki-laki dan Guru Perempuan 


\begin{tabular}{lclllllll}
\hline & \multirow{2}{*}{ No } & Nomor & \multicolumn{1}{c}{ Selalu } & \multicolumn{4}{c}{ Sering } & \multicolumn{3}{r}{ Kada } \\
& item & L & P & L & P & L & P \\
1 & 1 & 0 & 0 & 0 & 0 & 8 & 7 \\
2 & 2 & 0 & 0 & 0 & 14 & 8 & 43 \\
3 & 3 & 8 & 7 & 8 & 0 & 8 & 14 \\
4 & 4 & 8 & 14 & 0 & 0 & 46 & 5 \\
5 & 5 & 0 & 0 & 0 & 0 & 0 & 0 \\
6 & 6 & 0 & 0 & 8 & 0 & 23 & 14 \\
7 & 7 & 0 & 0 & 0 & 0 & 8 & 0 \\
8 & 8 & 0 & 0 & 8 & 0 & 23 & 50 \\
9 & 9 & 15 & 0 & 23 & 14 & 31 & 43 \\
10 & 10 & 0 & 0 & 0 & 0 & 8 & 7 \\
11 & 11 & 0 & 0 & 8 & 0 & 23 & 29 \\
12 & 12 & 0 & 0 & 0 & 0 & 0 & 0 \\
\hline
\end{tabular}

\section{Keterangan}

$\mathrm{L}=$ guru laki-laki

$\mathrm{P}=$ guru perempuan

\section{Bunyi pernyataan item nomor:}

1. Siswa berpakaian acak-acakan di kelas

2. Siswa yang datang terlambat ke kelas saat jam pelajaran sudah dimulai

3. Siswa ribut meminjam alat tulis teman saat guru menerangkan materi pelajaran.

4. Siswa berbicara dengan teman saat guru menjelaskan materi pelajaran

5. Siswa saling melempar benda dengan teman di hadapan guru yang sedang menjelaskan materi pelajaran.

6. Siswa bertanya dengan bahasa yang tidak baku/tidak benar dan mengandung unsur negatif dari materi pelajaran sehingga menimbulkan reaksi tertawa.

7. Siswa yang makan dalam kelas saat kegiatan inti pembelajaran berlangsung.

8. Siswa melakukan tingkah laku aneh yang memancing siswa lain tertawa.
9. Siswa tidur saat jam pelajaran berlangsung.

10. Siswa keluar kelas tanpa izin

11. Siswa tidak mengerjakan tugas

12. Siswa pulang sebelum jam pelajaran selesai

Dari data di atas dapat dilihat bahwa guru laki-laki dan perempuan menemukan bentuk PSM no 4 yaitu siswa berbicara dengan temannya saat guru menjelaskan materi pelajaran, selalu terjadi di kelas. Namun persentase jawaban guru laki-laki (8\%) lebih sedikit dari persentase jawaban selalu guru perempuan (14\%). Perilaku mengganggu tersebut dan perilaku memancing siswa lain tertawa sehingga mengganggu suasana pembelajaran, kadangkadang terjadi. Selain itu ada data yang unik yaitu menurut sebagian kecil (15\%) guru lakilaki, siswa selalu tidur dalam kelas, sementara tidak ada satupun guru perempuan yang mengemukakan hal itu. 
b. Bentuk PSM mencari kekuasaan (powertabel berikut : seeking behaviors), digambarkan dalam

Tabel 4

Bentuk Perilaku power-seeking behaviorssaat Pembelajaran di Kelas menurut Guru Laki-laki dan Guru Perempuan

\begin{tabular}{|c|c|c|c|c|c|c|c|c|c|c|c|}
\hline \multirow{3}{*}{ No } & \multirow{3}{*}{$\begin{array}{c}\text { Nomor } \\
\text { item }\end{array}$} & \multicolumn{10}{|c|}{ \% JAWABAN GURU } \\
\hline & & \multicolumn{2}{|c|}{ Selalu } & \multicolumn{2}{|c|}{ Sering } & \multicolumn{2}{|c|}{ Kadang } & \multicolumn{2}{|c|}{ Jarang } & \multicolumn{2}{|c|}{ Tdk Pernah } \\
\hline & & $\mathrm{L}$ & $\mathrm{P}$ & $\mathrm{L}$ & $\mathrm{P}$ & $\mathrm{L}$ & $\mathrm{P}$ & $\mathrm{L}$ & $\mathrm{P}$ & $\mathrm{L}$ & $\mathrm{P}$ \\
\hline 1 & 13 & 0 & 0 & 0 & 0 & 8 & 0 & 38 & 43 & 54 & 57 \\
\hline 2 & $14-18$ & 0 & 0 & 8 & 0 & 15 & 7 & 31 & 29 & 46 & 64 \\
\hline 3 & 19 & 0 & 0 & 0 & 0 & 0 & 14 & 46 & 29 & 54 & 57 \\
\hline 4 & 20 & 0 & 0 & 0 & 0 & 15 & 7 & 62 & 50 & 23 & 43 \\
\hline 5 & 21 & 0 & 0 & 0 & 0 & 0 & 7 & 38 & 64 & 62 & 29 \\
\hline 6 & 22 & 0 & 0 & 0 & 0 & 8 & 0 & 8 & 21 & 84 & 79 \\
\hline
\end{tabular}

Keterangan :

$\mathrm{L}=$ guru laki-laki

$\mathrm{P}=$ guru perempuan

Bunyi pernyataan item nomor:

13. Siswa membantah guru.

14-18 Siswa menggunakan laptop / handphone saat guru menjelaskan materi pelajaran

19. Siswa berjalan hilir mudik dalam kelas.

20. Siswa mengganggu teman.

21. Siswa menyela pembicaraan guru tanpa izin.
22. Siswa meniru ucapan guru yang menggangu.

Persentase untuk jawaban selalu dari bentuk perilaku jenis power-seeking behaviorsini ternyata tidak ada $(0 \%)$ menurut guru laki-laki dan guru perempuan.Namun ada guru laki-laki (8\%) menyatakan perilaku siswa menggunakan laptop atau handphone saat guru menjelaskan materi pelajaran sering terjadi.Hal ini berbeda dengan jawaban guru perempuan $(0 \%)$.

c. Bentuk PSM yaitu membalas dendam (reverenge-seeking behavior), digambarkan dalam tabel berikut:

Tabel 5

Bentuk Perilaku reverenge-seeking behaviorsaat Pembelajaran di Kelas menurut Guru Laki-laki dan Guru Perempuan

\begin{tabular}{|c|c|c|c|c|c|c|c|c|c|c|c|}
\hline \multirow{3}{*}{ No } & \multirow{3}{*}{$\begin{array}{c}\text { Nomor } \\
\text { item }\end{array}$} & \multicolumn{10}{|c|}{$\%$ JAWABAN GURU } \\
\hline & & \multicolumn{2}{|c|}{ Selalu } & \multicolumn{2}{|c|}{ Sering } & \multicolumn{2}{|c|}{ Kadang } & \multicolumn{2}{|c|}{ Jarang } & \multicolumn{2}{|c|}{ Tdk Pernah } \\
\hline & & $\mathrm{L}$ & $\mathrm{P}$ & $\mathrm{L}$ & $\mathrm{P}$ & $\mathrm{L}$ & $\mathrm{P}$ & $\mathrm{L}$ & $\mathrm{P}$ & $\mathrm{L}$ & $\mathrm{P}$ \\
\hline 1 & 23 & 0 & 0 & 0 & 0 & 8 & 7 & 38 & 36 & 54 & 57 \\
\hline 2 & 24 & 0 & 0 & 0 & 0 & 0 & 0 & 8 & 7 & 92 & 93 \\
\hline 3 & 25 & 0 & 0 & 0 & 0 & 0 & 0 & 0 & 7 & 100 & 93 \\
\hline 4 & 26 & 0 & 0 & 0 & 0 & 0 & 0 & 23 & 14 & 77 & 86 \\
\hline
\end{tabular}




\begin{tabular}{llllllllllll}
\hline 5 & 27 & 0 & 0 & 0 & 0 & 0 & 7 & 38 & 29 & 62 & 64 \\
6 & 28 & 0 & 0 & 0 & 0 & 0 & 0 & 15 & 21 & 85 & 79 \\
7 & 29 & 0 & 7 & 8 & 0 & 8 & 29 & 46 & 50 & 38 & 14 \\
8 & 30 & 0 & 0 & 0 & 0 & 0 & 7 & 15 & 43 & 85 & 50 \\
\hline
\end{tabular}

Keterangan

$\mathrm{L}=$ guru laki-laki

$\mathrm{P}=$ guru perempuan

Bunyi pernyataan item nomor:

23. Siswa berbicara atau bertindak keras pada teman

24. Siswa secara langsung menolak perintah guru

25. Siswa melakukan perlawanan pada guru baik secara fisik.

26. Siswa melawan perintah guru dengan kata-kata

27. Siswa mengambil benda milik teman tanpa izin.

28. Siswa merusak benda milik teman.

29. Siswa mengotori ruangan kelas

30. Siswa sengaja merusak perabotan yang ada dalam kelas

Dari gambaran tabel di atas dapat dilihat bahwa $7 \%$ guru perempuan menyatakan siswa mengotori ruang kelas dan $8 \%$ guru laki-laki menyatakan hal itu sering dilakukan siswa.Secara umum dari persentase jawaban guru laki-laki dan perempuan bentuk PSM dalam kategori ini tidak banyak terjadi.

d. Bentuk PSM yaitu menampilkan ketidakmampuandigambarkan dalam tabel berikut:

Tabel 6

Bentuk Perilaku Siswa Menampilkan KetidakmampuanSaat Pembelajaran di Kelas menurut Guru Laki-laki dan Guru Perempuan

\begin{tabular}{lcccccccccccc}
\hline & \multirow{2}{*}{ No } & \multicolumn{1}{c}{ Nomor } & \multicolumn{1}{c}{ Selalu } & \multicolumn{4}{c}{ Sering } & \multicolumn{3}{c}{ Kadang } & \multicolumn{3}{c}{ Jarang } & \multicolumn{2}{c}{ Tdk Pernah } \\
& item & L & P & L & P & L & P & L & P & L & P \\
\hline 1 & $31-33$ & 0 & 0 & 0 & 0 & 0 & 7 & 15 & 43 & 85 & 50 \\
2 & 34 & 0 & 0 & 0 & 0 & 31 & 36 & 31 & 50 & 38 & 14 \\
\hline
\end{tabular}

Keterangan

$\mathrm{L}=$ guru laki-laki

$\mathrm{P}=$ guru perempuan

Bunyi pernyataan item nomor:

31-33. Siswa mengeluh tidak mampu mengerjakan tugas.

34. Siswa tidak mampu melakukan apaapa yang disuruh guru
Data dalam tabel di atas, menunjukkan bahwa secara umum guru laki-laki maupun guru perempuan tidak pernah menemukan bentuk PSM dengan menampilkan ketidakmampuan ini.

\section{Penanganan PSMoleh guru}


Pengolahan angket mengungkap perbedaan penanganan PSM oleh guru laki-laki dan perempuan dengan program
SPSS menggunakan analisis t-test dapat digambarkan sebagai berikut:

Tabel 7

Uji t-test penanganan PSM oleh guru laki-laki dan perempuan

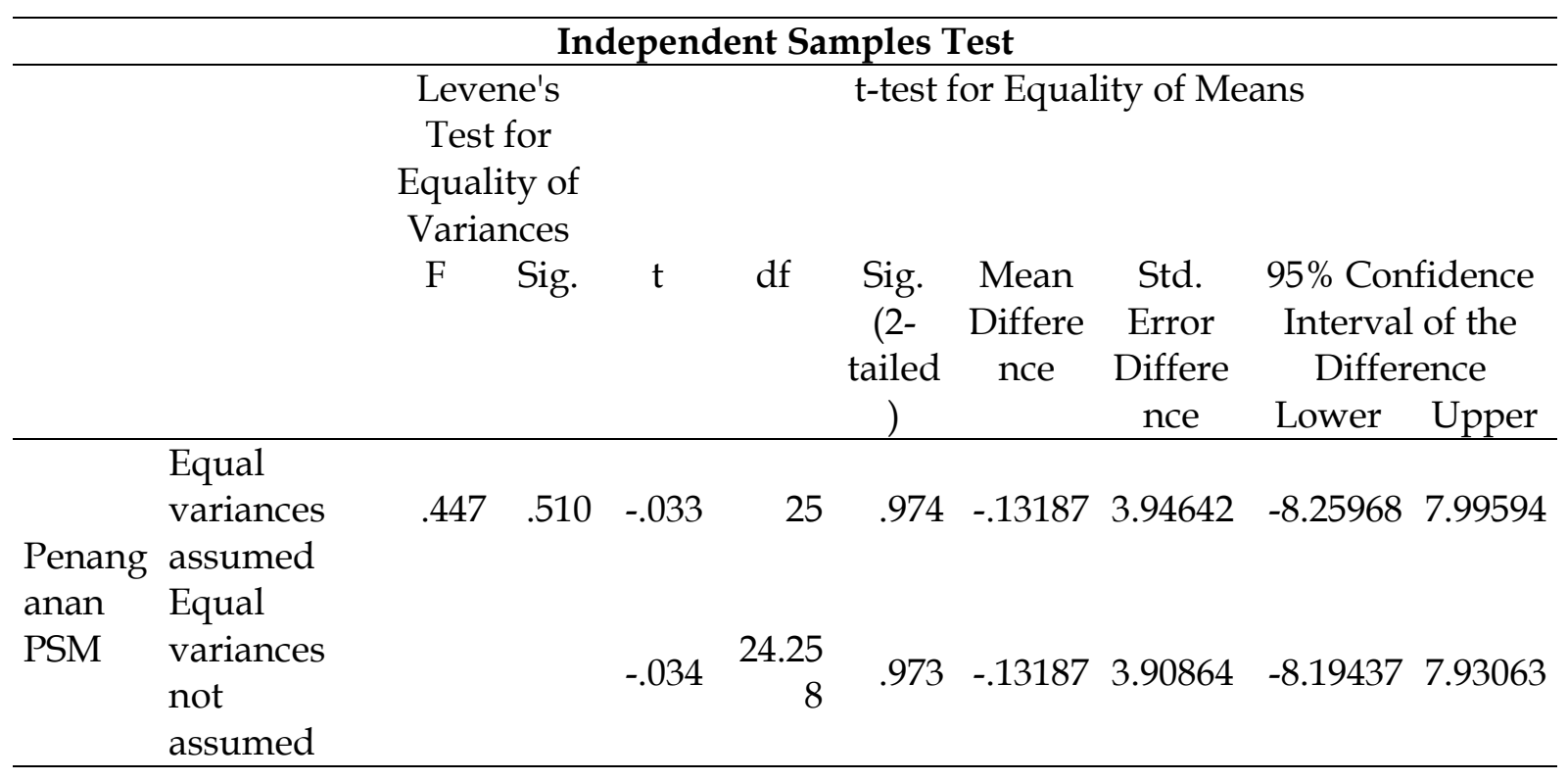

Hasil uji t-test ini menggambarkan levene's test $\mathrm{p}=0.510>0,05$ yang berarti data homogen. Hasil t-tes for equality of mean diperoleh bahwa $\mathrm{p}=0.974$ dan $\mathrm{p}=0.973>$ dari 0,05 yang berarti tidak ada perbedaan penanganan PSM menurut guru perempuan

Tabel 8

Perbedaan Mean Penanganan PSM oleh guru laki-laki dan guru perempuan

\begin{tabular}{ll|r|r|r|r}
\hline & \multicolumn{5}{c}{ Group Statistics } \\
& Guru & \multicolumn{1}{c}{ M } & \multicolumn{1}{c}{ Mean } & \multicolumn{1}{c}{$\begin{array}{c}\text { Std. } \\
\text { Deviation }\end{array}$} & \multicolumn{1}{c}{$\begin{array}{c}\text { Std. Error } \\
\text { Mean }\end{array}$} \\
\hline \multirow{2}{*}{$\begin{array}{l}\text { Penanganan } \\
\text { PSM }\end{array}$} & $\begin{array}{l}\text { Peremp } \\
\text { uan } \\
\text { laki- } \\
\text { laki }\end{array}$ & 14 & 102.7143 & 11.39790 & 3.04622 \\
& 13 & 102.8462 & 8.83031 & 2.44909 \\
\hline
\end{tabular}

Data dalam tabel tersebut memperlihatkan bahwa guru laki-laki melakukan penanganan PSM lebih tegas dibandingkan dengan guru dan guru laki-laki. Untuk melihat lebih spesifik dari dari rerata means yang dimiliki dari skor penanganan PSM oleh guru perempuan dan laki-laki sebagaimana dapat dilihat dalam tabel berikut: 
dibanding guru perempuan, namun perbedaan ini tidak signifikan.

\section{ANALISIS DAN REKOMENDASI PENELITIAN}

Dari hasil penelitian ini dapat disimpulkanperilaku siswa yang mengganggu (PSM) dalam proses pembelajaran klasikal memang terjadi, meskipun tidak dalam kategori sering atau banyak terjadi.Meskipun sedikit terjadi, harus ada penanganan terhadap PSM karena akan berlarut-larut dan mengganggu suasana pembelajaran. Ketika PSM tidak ditangani maka akan ada peningkatan frekuensi terjadinya

Ternyata guru perempuan lebih merasakan adanya PSM dalam proses pembelajaran dibandingkan dengan guru laki-laki.Guru perempuan menilai bentuk PSM lebih tinggi dibandingkan dengan guru laki-laki (22.2143 > 209231). Namun perbedaan ini tidak signifikan.

Temuan penelitian ini ditegaskan oleh A.G. Hughes \& E.H.Hughes ${ }^{16}$ bahwa perilaku siswa yang mengganggu (PSM) bisa terjadi dalam proses pembelajaran klasikal dengan pendidik yang berbakat sekalipun, karena adanya kecenderungan naluriah yang dapat menguat secara tak normal pada diri peserta didik ketika proses pembelajaran tidak terkendali. Artinya baik saat pembelajaran oleh guru laki-laki maupun perempuan bahkan guru yang berbakat sekalipun akan ditemukan PSM. Kecenderungan naluriah yang terjadi pada siswa tersebut diistilahkan dengan "energi liar" oleh Prayitno. ${ }^{17}$

Lebih jauh dijelaskan "energi liar" muncul dari kesenjangan dan guncangan atas berbagai peristiwa yang dialami individu di masyarakat, keluarga dan anggota masyarakat. ${ }^{18}$ Wujud PSM sebagai "energi liar" tersebut ${ }^{19}$ seperti "....berbuat gaduh meskipun guru sudah masuk kelas, tidak memperhatikan guru yang sedang menerangkan pelajaran dan sebagainya".

Hasil penelitian ini membuktikan bahwa baik guru laki-laki dan perempuan pada hakekatnya sama-sama mengharapkan kondisi pembelajaran yang aktif, dinamis, proaktif, dan dikehendaki tanpa gangguan. Penelitian Kounin dan Doyle dan Carter ${ }^{20}$ menegaskan bahwa hasil belajar yang optimal paling mungkin dicapai siswa di kelas yang tertib.

Untuk mencapai tujuan pembelajaran, baik guru laki-laki dan perempuan sama mengharapkan siswanya berpartisipasi aktif melakukan lima kegiatan sebagai implementasi dinamika belajar yaitu berpikir (B), merasa (M), bersikap (B), bertindak (B) dan bertanggungjawab (B), selanjutnya disingkat dengan istilah BMB3.21 Sehingga pembelajaran yang terjadi di kelas, khususnya sekolah menengah dapat menjadi ujung tombak penentu pencapaian tujuan 
pada jenjang pendidikan lanjutan yaitu perguruan tinggi. Yamin ${ }^{22}$ menegaskan:

Sekolah yang bisa menjadi harapan masa depan adalah ketika memberikan sebuah perspektif berbeda dalam melakukan sebuah kegiatan belajar mengajar dalam kelas. Salah satu cara mengetahui apakah sekolah itu merupakan sebuah cerminan masa depan ialah dilihat dari proses yang terjadi dalam kelas.

Kenyataan dari hasil penelitian ini bahwa bentuk PSMmenurut guru laki-laki dan perempuan,dominan pada kategori attention-getting behaviors/mencari perhatian, seperti bicara dengan teman saat guru menjelaskan materi pelajaran dan melakukan tingkah laku aneh yang memancing siswa lain tertawa. Dalam hal ini Walter Doyle (1986) dalam Supriadi $\&$

Darmawan ${ }^{23}$ menjelaskan bahwa lingkungan kelas memiliki karakteristik yang merefleksikan kompleksitas dan potensi terjadinya problema yaitu:(1) Kelas adalah multideminsional; maksudnya kelas adalah setting untuk banyak aktivitas, mulai dari aktivitas akademik seperti membaca, menulis, dan matematika, sampai aktivitas sosial, seperti bermain, berkomunikasi dengan teman dan berdebat. Guru harus mencatat jadwal dan membuat siswa menurutinya. Tugas diberikan guru dan dimonitor, dikoleksi, dan dievaluasi, (2) Aktivitas yang terjadi di kelas terjadi secara simultan; satu kelompok siswa mungkin mengerjakan tugas menulis, yang lain mendiskusikan atau mengerjakan tugas lain, (3) Hal-hal yang terjadi secara cepat dalam kelas; kejadian terjadi antar siswa seperti berdebat, mengeluh karena ada yang mencontek, bertengkar, yang semuanya itu membutuhkan respon cepat dari guru, (4) Kejadian sering kali tidak bisa diprediksi dalam kelas; misalnya ada siswa yang tibatiba sakit, alarm kebakaran berbunyi, Hanya ada sedikit privasi; kelas adalah tempat publik dimana siswa melihat bagaimana guru mengatasi masalah, melihat kejadian tidak terduga dan mengalami frustrasi, (6) Kelas punya sejarah; siswa dan guru (laki-laki dan perempuan) punya kenangan tentang apa yang terjadi di kelas pada waktu sebelumnya. Alasan ini perlu dipahami dan disadari oleh guru laki-laki dan perempuan.

Ternyata guru laki-laki menangani PSM lebih tegas dibandingkan dengan guru perempuan, namun perbedaan ini tidak signifikan.Hasil penelitian ini merekomendasikan bahwa guru perempuan harus meningkatkan ketegasan dan menguasai strategi tindakan tegas yang mendidik (TTM) dalam menangani PSM.Guru perempuan harus memahami bahwa tegas yang dimaksud adalah tidak melihat siswa sebagai musuh, juga tidak menggunakan abrasif, sarkastik, gaya bermusuhan. Guru yang tegas tidak bereaksi dengan pasif, tidak konsisten, atau pemalu. Guru yang tegas percaya bahwa kelas 
ibaratkan sebuah perusahaan, guru memberikan pelayanan terbaik adalah demi kepentingan siswa.Mereka percaya bahwa siswa ingin memiliki keamanan pribadi dan psikologis yang mereka perolah dari guru mereka yang sangat berkompeten dalam mengarahkan perilaku. Guru perempuan dengan naluri keibuan yang dimilikinya akan sanggup melakukan tindakan tegas yang mendidik tersebut.

Temuan penelitian menunjukkan bahwa perilaku mengganggu yang ditunjukkan siswa dalam pembelajaran ternyata tidak memicu guru laki-laki dan perempuan untuk melakukan tindakan malapraktik pendidikan seperti menghukum. "Menghukum dan kekerasan" bukan tindakan yang direkomendasikan bagi penanganan PSM bagi guru laki-laki dan perempuan.

Prayitno ${ }^{24}$ menjelaskan guru dituntut untuk dapat "tegas dalam mendidik" siswa yang mengganggu, bukan menghukumnya. Perbedaan Tindakan guru yang tegas dalam mendidik dengan tindakan tegas yang menghukum menurut Prayitno ${ }^{25}$ sebagaimana diuraikan dalam tabel berikut:

Tabel 9

Perbedaan Tindakan Tegas Mendidik (TTM) dan Tegas Menghukum

\begin{tabular}{|c|c|c|c|}
\hline No & Aspek & TTM & Tegas yang Menghukum \\
\hline 1 & $\begin{array}{l}\text { Energi dan } \\
\text { landasan } \\
\text { pendidik }\end{array}$ & $\begin{array}{l}\text { Positif, kasih sayang, pengakuan, } \\
\text { penerimaan dan kelembutan }\end{array}$ & $\begin{array}{lr}\text { Negatif, } & \text { menekankan } \\
\text { kekuasaan, } & \text { kemarahan, } \\
\text { tersinggung, } & \text { merasa } \\
\text { dirugikan } & \end{array}$ \\
\hline 2 & $\begin{array}{l}\text { Pandangan } \\
\text { pendidik } \\
\text { tentang } \\
\text { peserta didik } \\
\text { yang } \\
\text { melakukan } \\
\text { tingkah laku } \\
\text { menyimpan }\end{array}$ & $\begin{array}{l}\text { Peserta didik harus dicegah } \\
\text { terjerumus (lebih jauh/lebih } \\
\text { dalam) kearah kesalahan yang } \\
\text { merugikan dirinya }\end{array}$ & $\begin{array}{l}\text { Peserta didik adalah orang } \\
\text { muda yang belum banyak } \\
\text { pengalaman, harus patuh } \\
\text { dan objek yang boleh } \\
\text { diperlakukan apa saja oleh } \\
\text { pendidik }\end{array}$ \\
\hline 3 & $\begin{array}{l}\text { g } \\
\text { Tujuan }\end{array}$ & $\begin{array}{l}\text { 1) Subjek pelaku menjadi tahu } \\
\text { mana yang salah dan mana } \\
\text { yang benar berkenaan dengan } \\
\text { peristiwa yang dikenai TTM } \\
\text { 2) Disadarkan bahwa dirinya } \\
\text { sebenarnya mampu berbuat } \\
\text { yang lebih baik dari pada } \\
\text { melakukan perilaku } \\
\text { menyimpang yang dikenai TTM } \\
\text { itu dirinya } \\
\text { 3) Merasa dihargai karena dirah } \\
\text { tidak direndahkan bahkan } \\
\text { diarahkan bahwa dirinya itu }\end{array}$ & $\begin{array}{l}\text { Membentuk } \\
\text { bersyarat }\end{array}$ \\
\hline
\end{tabular}




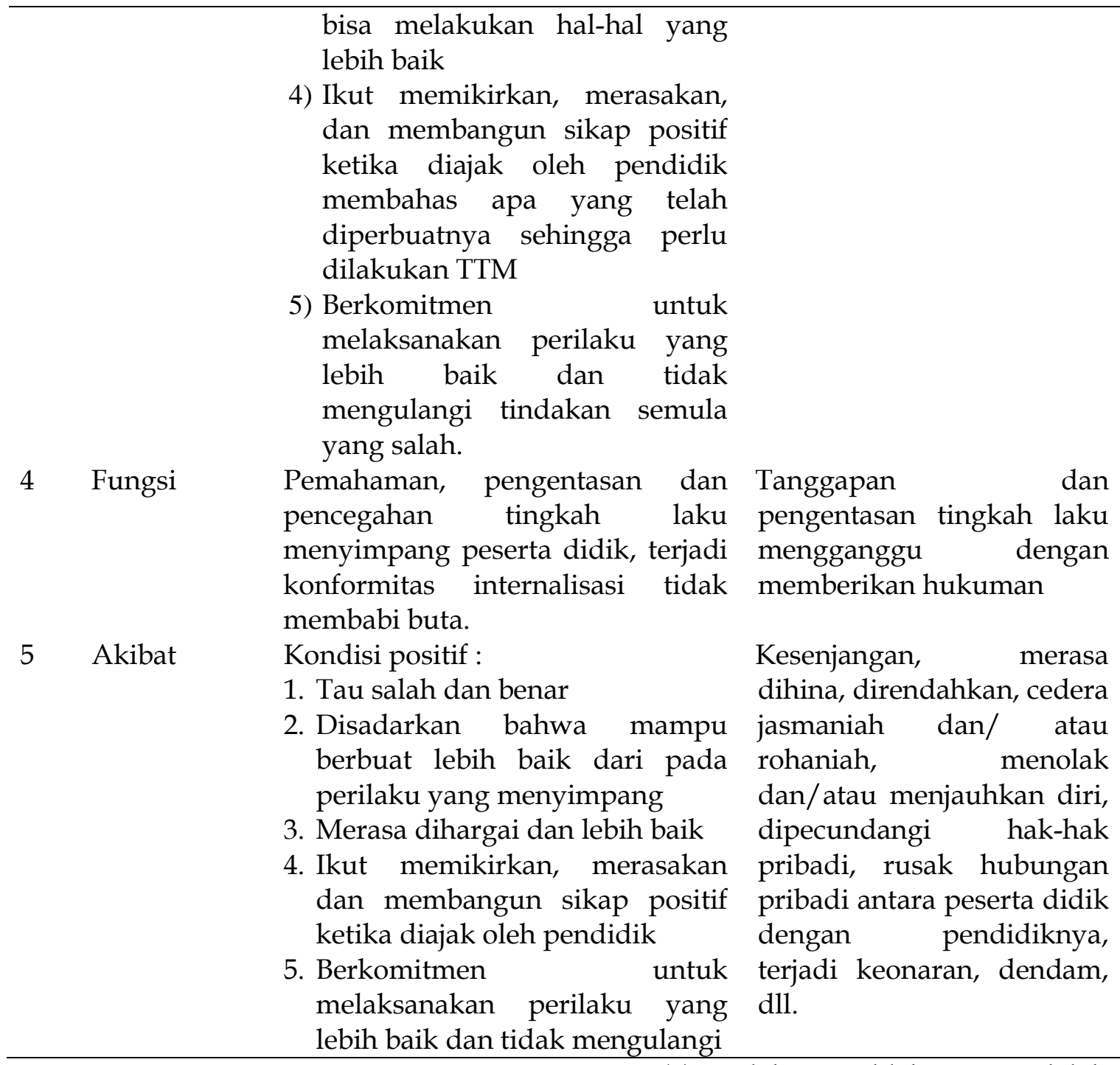

Jika kita analisis lebih jauh lagi dalam konteks pendidikan Islam, ketegasan terhadap PSM oleh seorang pendidik baik itu guru laki-laki dan perempuanberarti mengimplementasikan semua ajaran Allah dan Nabi Muhammad SAW dalam menyiapkan generasi penerus, dan ini akan mendukung program Sekolah Ramah Anak (SRA).ImplementasiPeraturan Menteri Negara Pemberdayaan Perempuan dan Perlindungan Anak Republik Indonesia Nomor 8 Tahun 2014, Sistem SRA yaitu: sikap guru terhadap murid yang diatur yaitu;
(1) Perlakuan adil bagi murid laki-laki dan perempuan, cerdas-lemah, kaya-miskin, normal-cacat, anak pejabat-anak buruh, (2) Penerapan norma agama, sosial dan budaya setempat,(3) Kasih sayang kepada murid, memberikan perhatian bagi mereka yang lemah dalam proses belajar karena memberikan hukuman fisik maupun nonfisik bisa menjadikan anak trauma,(4) Saling menghormati hak-hak anak, baik antar murid, antar tenaga, kependidikan serta antara tenaga kependidikan dan murid. Adapun metode pembelajaran yang harus diterapkan guru adalah; (1) Terjadi proses 
belajar sedemikian rupa sehingga peserta didik merasakan senang mengikuti pelajaran, tidak ada rasa takut, cemas dan was-was, peserta didik menjadi lebih aktif dan kreatif serta tidak merasa rendah diri karena bersaing dengan teman peserta didik lain.

Terkait dengan implementasi ketegasan yang mendukung sekolah ramah anak oleh guru laki-laki dan perempuan seperti di atas, perlu diperhatikan aspek efektivitas prosedur pengubahan tingkah laku negatif siswa menurut Jansen ${ }^{26}$ yaitu harus: (a) mampu menyelesaikan masalah yang berulang-ulang, (b) berlaku untuk setiap orang, (c)sederhana dan mudah dilakukan, (d) bisa diramalkan siswa tahu kapan akan terjadi dan (e) menempatkan siswa dalam keadaan emosional yang positif, tidak ketakutan, cemas apalagi tertekan. Berdasarkan aspek efektivitas ini, guru lakilaki dan perempuan dapat melihat tindakannya dalam menangani PSM, apakah berupa ketegasan dalam mendidik atau menghukum. Ketika memberikan hukuman, siswa berada pada posisi emosional yang tertekan, ketakutan sehingga tingkah laku negatif yang diharapkan berubah kearah positif tidak akan terjadi.

Hal ini penting dipahami karena ketika hukuman dalam pendidikan dilakukan, pendidik sudah terjebak dalam lingkaran kesalahan dan sulit mewujudkan harapan untuk membentuk perilaku positif siswa. Muh. Nabil Kazhim ${ }^{27}$ mengutip pendapat Umar Basyir Att Thuwaibi mengatakan bahwa:

Punishment adalah pintu negatif dalam pendidikan. Ia akan menggiring seseorang menuju kehancuran, sehingga hidup dalam kecemasan, ketakutan, dan kegagalan. Sesungguhnya kebiasaan memukul anak dalam mendidiknya menunjukkan bahwa kita sebagai orang dewasa salah dalam memilih metode yang tepat sehingga dapat menyentuh jiwa dan meluruskan perilakunya.

Terkait dengan itu Supriadi \& Darmawan $^{28}$ menguraikan manakala ada siswa yang menimbulkan gangguan atau menunjukkan ketidakacuhan maka guru dapat memberikan reaksi dalam bentuk teguran. Tindakan ini menyatakan bahwa "ada guru bersama mereka". Tindakan ini dilakukan dengan segera dan akan mencegah meluasnya tingkah laku yang mengganggu tersebut. Tindakan menegur secara verbal atau mengingatkan kepada siswa tersebut dilakukan secara efektif, dengan memperhatikan hal berikut: (a) Teguran harus jelas dan tegas dan ditujukan kepada siswa yang mengganggu, serta ditujukan untuk menghentikan tingkah laku mengganggunya, Hindari teguran/peringatan yang kasar, menyakitkan atau mengandung unsur penghinaan, (c) Hindari teguran/mengingatkan yang 
bermuatan ejekan, atau ocehan yang berkepanjangan.

Bagaimanapun, guru laki-laki dan perempuan dituntut harus menjalankan tugasnya sebagai pendidik secara profesional yang ditunjukkan dengan melakukan tindakan tegas yang mendidik pada pelaku PSM. Sehingga siswa yang memiliki "energiliar" saat pembelajaran berlangsung tidak dihukum atau dibiarkan, melainkan dirubah perilakunya menjadi positif.

Guru adalah pahlawan tanpa tanda jasa, dan jasanya tak terbalas dalam mencerdaskan anak bangsa. Suksesnya guru merubah tingkah laku siswa ke arah yang positif dalam pembelajaran, akan menggambarkan kesuksesan sekolah dalam mewujudkan tujuan pendidikan.

\section{Endnotes:}

1 Ansyar, Mohamad. 2015. Kurikulum Hakikat, Fondasi, Desain dan Pengembangan. Jakarta: Kencana Prenamedia Group. Hal 3 Ibid

Ibid

4 Mulyadi. 2009. Classroom Management. Malang: UIN Malang Press, hal. 4

5 Sri Sukarti ,(2013). Isu Gender Dan Sertifikasi Guru Versus Prestasi Belajar Siswa .Jurnal Pendidikan, Volume 14, Nomor 1, Maret 2013, hal.38-43

6 T'uu, Tulus. 2004. Peran Disiplin Pada Perilaku dan Prestasi Sisiwa. Jakarta: Gramedia Widiasarana Indonesia

7 Arends, Richard I. 2013.Belajar untuk Mengajar Edisi 9 Buku 1.Terjemahan oleh Made Feida Yulia. Jakarta: Salemba, hal. 199

8 Partin, L., Ronald. 2009. KIat Nyaman Mengajar di dalam Kelas. Jakarta: Indeks. hal. 44

9 Arends, Richard I.,2013, Op.Cit, hal. 207

10 Ibid, hal. 200
11 http://www. pikiran-rakyat com/pendidikan /2016/01/25)

12 Prayitno. 2009. Dasar Teori dan Praksis Pendidikan. Jakarta: Grasindo, hal. 168

13 Prayitno. 2013. Kaidah Keilmuan Pendidikan dalam Belajar dan Pembelajaran. Padang: UNP Press, hal. 212)

14 Kazhim, Muhammad Nabil. 2011. Sukses Mendidik Anak Tanpa Kekerasan. Solo: Samudra, hal. 44)

15 Ibid, hal. 27

16 A.G. Hughes \& E.H.Hughes. 2003 . Learning $\mathcal{E}$ Teaching Pengantar Psikologi pembelajaran Modern. Bandung: Nuansa, hal. 363)

17 Prayitno. 2013. Kaidah Keilmuan Pendidikan dalam Belajar dan Pembelajaran. Padang: UNP Press, hal. 154).

18 Ibid

19 Prayitno. 2009. Op.Cit, hal. 167

20 Arends, Richard I. 2013.Belajar untuk Mengajar Edisi 9 Buku 1.Terjemahan oleh Made Feida Yulia. Jakarta: Salemba, hal. 191)

21 Prayitno. 2014. Pembelajaran Melalui Pelayanan BK di Satuan Pendidikan. Padang: UNP Press. hal. 14

22 Yamin.Moh. 2012. Sekolah yang Membebaskan. Malang: Madani, hal. 160

23 Supriadi, Didi \& Darmawan, Deni. 2012. Komunikasi Pembelajaran. Bandung: PT Remadja Rosdakarya, hal. 163

24 Prayitno. 2013. Kaidah Keilmuan Pendidikan dalam Belajar dan Pembelajaran. Padang: UNP Press

25 Ibid

26 Jensen, Eric. 2010. Guru Super dan Super Teaching. Jakarta: PT. Indeks. hal. 214

27 Kazhim, Muhammad Nabil. 2011. Sukses Mendidik Anak Tanpa Kekerasan. Solo: Samudra, hal. 27)

28 Supriadi, Didi \& Darmawan, Deni. 2012. Komunikasi Pembelajaran. Bandung: PT Remadja Rosdakarya, hal. 178 \&180)

\section{DAFTAR PUSTAKA}

A.G. Hughes \& E.H.Hughes. 2003 . Learning $\mathcal{E}$ Teaching Pengantar Psikologi pembelajaran Modern. Bandung: Nuansa.

Arends, Richard I. 2013.Belajar untuk Mengajar Edisi 9 Buku 1.Terjemahan 
oleh Made Feida Yulia. Jakarta: Salemba.

Colvin, Geoff. 2008. 7 Langkah Untuk Menyusun Rencana Disiplin Kelas Proaktif.Jakarta: PT. Indeks.

Harley, Joan C \& Sidney T Rowland. 2002. Behavior Modification for Teacher. Charles C Thomas Publisher

Kazhim, Muhammad Nabil. 2011. Sukses Mendidik Anak Tanpa Kekerasan. Solo: Samudra

McDonald, Emma S.dkk .2012. Pembelajaran yang Menyenangkan. Jakarta: Erlangga.

Mulyadi. 2009. Classroom Management. Malang: UIN Malang Press.

Prayitno dan Belferik Manulang. 2010.Pendidikan Berkarakter dalam Pembangunan Bangsa. Medan: PPs Universitas Negeri Medan.

Prayitno. 2009. Dasar Teori dan Praksis Pendidikan. Jakarta: Grasindo

Prayitno. 2013. Kaidah Keilmuan Pendidikan dalam Belajar dan Pembelajaran. Padang: UNP Press.

Sri Sukarti ,( 2013). Isu Gender Dan Sertifikasi Guru Versus Prestasi Belajar Siswa . Jurnal Pendidikan, Volume 14, Nomor 1, Maret 2013, 3843

Supriadi, Didi \& Darmawan, Deni. 2012. Komunikasi Pembelajaran. Bandung: PT Remadja Rosdakarya.

Wardah, Fathiyah. (2012). "KPAI Imbau Pemerintah Lebih Serius Atasi Kekerasan Anak dalam Lingkup Pendidikan" (online). (http://m.voaindonesia.com/a/ 1562622.html)
Yamin.Moh. 2012. Sekolah yang Membebaskan. Malang: Madani. 